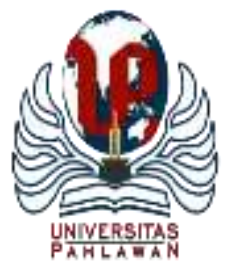

Edukatif : Jurnal Ilmu Pendidikan Volume 3 Nomor 4 Tahun 2021 Halm 2400 - 2410 EDUKATIF: JURNAL ILMU PENDIDIKAN

Research \& Learning in Education

https://edukatif.org/index.php/edukatif/index

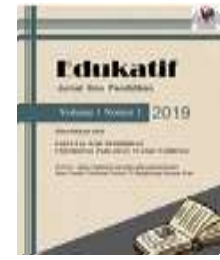

\title{
Manfaat Penggunaan Gadget terhadap Minat Belajar Siswa Pendidikan Kristen pada Era Postmodern
}

\author{
Anggi Maringan $\mathbf{H}^{1 凶}$, Yehezkiel V. Fernando ${ }^{2}$ \\ Sekolah Tinggi Teologi Bethel Indonesia ${ }^{1,2}$ \\ E-mail : anggimaringan.mia2@ gmail.com ${ }^{1}, \underline{\text { Kiellfernando@gmail.com }}^{2}$
}

\begin{abstract}
Abstrak
Postmodern dengan corak berpikir relativisme dan pluralismenya membawa perubahan mendasar dalam Pendidikan Agama Kristen yang berbanding lurus dengan kemajuan gadget dikalangan guru dan siswa-siswi. Dikhawatirkan dengan gadget yang dimiliki oleh siswa-siswa Kristen justru membuat mereka tidak mempercayai Alkitab dan Yesus sebagai sumber kebenaran. Tujuan penelitian ini adalah untuk mengetahui bagaimana teknologi dapat digunakan untuk mengelaborasi minat belajar siswa-siswi Pendidikan Kristen dan strategi guru Pendidikan Kristen dalam mempertahankan minat belajar siswa-siswi. Penelitian ini menggunakan metode kualitatif deskriptif dengan subjek penelitian siswa/i Sekolah Menengah Teologi Kristen (SMTK) Bethel Jakarta. Pengumpulan data dilakukan dengan wawancara terstruktur melalui google form kepada 30 informan, dan wawancara mendalam kepada 12 informan. Hasil penelitian menunjukkan bahwa siswa-siswi termotivasi belajar karena dalam proses belajar mengajar di kelas terdapat games online Quizizz. Games yang dihadirkan dalam kelas ini membuat mereka memahami materi pembelajaran dengan mudah dan pemaknaan yang benar akan games online. Games online juga mempermudah guru-guru SMTK Bethel Jakarta untuk internalisasi kebenaran Alkitab. Dapat disimpulkan bahwa penggunaan media belajar berbasis games dalam pembelajaran era postmodern dapat meningkatkan minat siswa-siswi dalam mempelajari Pendidikan Agama Kristen. Hal ini mesti dibarengi dengan pemahaman dan pengkontrolan dari guru-guru dalam penggunaan gadget siswa sehari-hari.
\end{abstract}

Kata Kunci: Gadget, Pendidikan Kristen, Postmodern.

\begin{abstract}
Postmodern with its relativism and pluralism thinking style brings fundamental changes in Christian Religious Education which is directly proportional to the advancement of gadgets among teachers and students. Worrying about the gadgets owned by Christian students actually makes them distrust the Bible and Jesus as the source of truth in life. The purpose of this study was to find out how technology can be used to elaborate the learning interest of Christian Education students and the strategies of Christian Education teachers in maintaining students' interest in learning. This study uses a descriptive qualitative method with the research subjects of Sekolah Menengah Teologi Kristen (SMTK) Bethel Jakarta. Data collection was carried out by structured interviews via google form to 30 informants, and in-depth interviews with 12 informants. The results showed that students were motivated to learn because in the teaching and learning process in the classroom there were Quizizz online games. The games presented in this class make them understand the learning material easily and the correct meaning of online games. Online games also make it easier for Bethel Jakarta SMTK teachers to internalize Bible truths. It can be concluded that the use of games-based learning media in postmodern era learning can increase students' interest in studying Christian Religious Education. This must be accompanied by understanding and control from teachers in the daily use of students' gadgets.
\end{abstract}

Keywords: Gadgets, Christian Education, Postmodern.

Copyright (c) 2021 Anggi Maringan H, Yehezkiel V. Fernando

Corresponding author

Email : anggimaringan.mia2@gmail.com

DOI : https://doi.org/10.31004/edukatif.v3i4.1114

ISSN 2656-8063 (Media Cetak)

ISSN 2656-8071 (Media Online)

Edukatif : Jurnal Ilmu Pendidikan Vol 3 No 4 Tahun 2021 p-ISSN 2656-8063 e-ISSN 2656-8071 
2401 Manfaat Penggunaan Gadget terhadap Minat Belajar Siswa Pendidikan Kristen pada Era Postmodern Anggi Maringan H, Yehezkiel V. Fernando

DOI: https://doi.org/10.31004/edukatif.v3i4.1114

\section{PENDAHULUAN}

Gadget sudah menjadi sahabat dalam hidup manusia. Dari bangun tidur, makan, minum, beraktifitas, berolahraga, berkantor, bersekolah bahkan membeli barang dapat dilakukan dengan menggunakan gadget. Tentu tidaklah berlebihan, sebab gadget menyajikan banyak fasilitas menarik yang membuatnya diminati oleh seluruh kalangan dan usia karena terdapat banyak fitur yang dapat digunakan untuk menonton, mendengar musik, sosial media, permainan dan mencari informasi. Dari penggunaan gadget di sosial media tentu memberi manfaat pada pemakai gadget tersebut, dari kegunaannya (Intan Trivena Maria Daeng et al., 2017).

Di Indonesia ini angka penggunaan gadget sudah melambung tinggi, begitu banyak pengguna gadget. Dilansir dari katadata.co.id, penggunaan ponsel pintar diprediksi akan terus mengalami peningkatan. Tahun 2018 saja terdapat 56,2\% populasi di Indonesia yang telah menggunakan gadget. Angka ini terus mengalami pertumbuhan pada tahun 2019 dengan angka 63,3\%. Diprediksi pada tahun 2025 nanti, akan terdapat sekitar 89,2\% populasi di Indonesia telah menggunakan gadget dalam melaksanakan aktivitas kehidupan mereka (Pusparisa, 2020) Angka ini tentunya menunjukan bahwa Indonesia mengalami kenaikan yang cukup signifikan dalam penggunaan gadget. Seluruh masyarakat Indonesia melek teknologi di era Internet of Things. Kemajuan ini dapat menjadi kabar yang menggembirakan jika keberadaan gadget dapat dimanfaatkan dengan tujuan yang baik. Namun sebaliknya, dapat menjadi boomerang yang merusak nilai-nilai kehidupan yang telah terbangun. Contoh situs-situs dewasa yang ada dalam dunia internet dengan mudah bisa diakses sehingga perlu adanya bimbingan dari pemerintah, sekolah dan orang tua pada penggunaan gadget yang benar dan efektif.

Menarik kepada konteks Pendidikan secara umum dan Pendidikan Agama Kristen secara khusus, Pandemic covid 19 membuat sekolah harus merubah pola belajarnya dari tatap muka (offline) menjadi tatap maya atau daring (online). Perubahan ini tentunya mengharuskan siswa/i memakai gadget berupa laptop, tablet dan lainnya sebagainya. Siswa menggunakan gadget sebagai sarana untuk pembelajaran pertemuan guru dan siswa/i. Internet menjadi kebutuhan primer para pelajar dalam melakukan kelas online, pemerintah memberikan sumbangsih berupa kuota bagi guru, mahasiswa dan murid. Keadaan ini tentunya membuat pengguna internet di kalangan pelajar meningkat drastis.

Selain untuk belajar karena sistem online memaksanya, banyak tujuan lain dari kegunaan gadget. Diantaranya untuk mencari hiburan melalui bermain game, seperti PUBG, Mobile Legend, dan Free Fire. Fakta ini tidaklah mengherankan karena itu adalah hiburan yang dapat dilakukan selama masa pandemic ini. Namun ini menjadi masalah tersendiri lagi sebab kajian dari sudut pandang sosiologis menyatakan bahwa seseorang yang memainkan games sampai kepada taraf candu termasuk seseorang yang egosentris dan mengedepankan individualis. Games online melupakan orang-orang yang ada disekitarnya yang menyebabkan tidak terjadinya interaksi sosial. Interaksi sosial yang terhambat dapat menyebabkan kemampuan dalam bersosialisasi siswa data menurun (Xiao, 2018) Bahkan yang lebih mengkhawatirkan dari kecanduan ini adalah prestasi belajar yang menurun. Jika tidak ditangani dengan segera, maka akan menjadi bola salju yang besar sampai kepada kelumpuhan sumber daya manusia yang berkualitas (Yulianti et al., 2020), khususnya dalam Pendidikan Agama Kristen

Menjadi persoalan dalam kehidupan siswa/i. Disatu sisi, kecanduan games, pengaksesan situs dewasa, dan kemudahan mengakses materi belajar PAK yang salah menghantui mereka, namun disisi lain minat belajar mesti tetap ditumbuh kembangkan. Dengan minat belajar siswa dapat memaksimalkan dirinya untuk dapat memberikan nilai yang memuaskan. Sehingga pembelajaran dapat berjalan lancar dan dapat dicerna dengan benar oleh siswa/i pendidikan Kristen (Hudaya, 2018).

Seharusnya, PAK harus membentuk siswa-siswi yang berkarakter kristus, tetapi faktanya, hal itu sulit dilakukan karena corak berpikir masyarakat postmodern dan kemajuan teknologi. Penelitian ini hendak mengeksplorasi kegunaan gadget menurut siswa/i SMTK Bethel Jakarta yang dikaitkan dengan strategi belajar 
yang dilaksanakan oleh guru-guru supaya Pendidikan Agama Kristes tetap dapat menginternalisasi nilai-nilai kebenaran Firman Tuhan di era postmodern. Melalui penelitian ini, Pendidikan Agama Kristen dapat tetap melahirkan lulusan yang berintegritas, hidup dalam kebenaran Firman Tuhan, dan tetap mempercayai Yesus sesuai dengan tujuan dari PAK di era postmodern dan kemajuan teknologi (disrupsi).

Penelitian yang selama ini dilakukan hanya berkaitan kepada manfaat dari gadget terhadap pembelajaran dikelas. Seperti Rosiyanti dan Muthmainnah yang menyoroti penggunaan gadget untuk hasil belajar Matematika yang lebih baik. Dengan metode penelitian kuantitatif, didapati 26,9\% dari siswa mendapatkan dampak lebih ketika belajar menggunakan gadget (Rosiyanti \& Muthmainnah, 2018). Lain halnya dengan Kurniawati membahas manfaat Gadget yang dikaitkan dengan prestasi dan didapati pengaruhnya sebesar 56\% (Kurniawati, 2020). Sedangan dalam taraf Pendidikan Agama Kristen, penelitian yang dilakukan oleh Eliasaputra dkk berfokus kepada tantangan yang muncul akibat era post-truth dan revolusi industri 4.0 (kemajuan teknologi) (Eliasaputra et al., 2020). Kalaupun ada yang membahas mengenai peran guru PAK, hanya sebatas dorongan abstrak supaya lebih bersungguh-sungguh dalam mendidik siswanya (Telaumbanua, 2018). Sedangkan dalam penelitian ini, sorotan diberikan kepada manfaat gadget dalam meningkatkan minat belajar PAK di era postmodern.

\section{METODE PENELITIAN}

Penelitian ini menggunakan metode kualitatif. Moleong menyatakan bahwa penelitian kualitatif adalah penelitian yang berupaya membangun pandangan terhadap fenomena yang sedang dialami (Moleong, 2010). Pengumpulan data menggunakan wawancara yang dilakukan dengan dua teknik, yaitu wawancara terstruktur (passive particioation) melalui survey google form kepada 30 responden, dan wawancara mendalam melalui media zoom meeting dan Whatsapp Call kepada 12 orang. Hal ini peneliti lakukan karena pandemic Covid-19 yang belum selesai ditangani dan pertemuan langsung yang dibatasi secara ketat oleh pemerintah. Sedangkan menurut Sugiyono bahwa pengumulan data bukan hanya dengan cara triangulasi data. Melainkan juga dengan setting yaitu dikumpulkannya data pada setting alamiah, pada labolatorium dengan metode eksperimen, di rumah dengan berbagai responden, pada suatu seminar atau diskusi (Sugiyono, 2015). Penelitian ini dilaksanakan pada awal Mei hingga akhir Juni 2021 di Sekolah Menengah Teologi Kristen Bethel (SMTK) Jakarta. Peneliti. Uji keabsahan data dilakukan dengan credibility, dan confirmability. Credibility dilakukan dengan memperpanjang penelitian yang seharusnya 42 hari, menjadi 60 hari. Hal ini dilakukan karena terdapat perbedaan kecil data ketika dua kali dilakukan survey melalui google form. Namun pada penyebaram google form yang ketiga, data relatif sama. Confirmability dilakukan dengan menyampaikan hasil survey dan wawancara kepada pihak sekolah SMTK Bethel Jakarta dan siswa-siswi yang menjadi narasumber.

\section{HASIL DAN PEMBAHASAN PENELITIAN}

\section{Minat belajar Siswa}

Minat belajar secara sederhana dipahami adalah rasa keinginan atau gairah yang timbul dalam hati seorang siswa-siswi dalam mengikuti pembelajaran di sekolah. Setiap siswa/i pasti memiliki kepintaran yang berbeda-beda, terdiri dari kepintaran Intelektual, linguistik, olahraga dan lain-lainnya (Kelellufna \& Masan, 2016) Namun tidak semua siswa/i memiliki minat atau gairah belajar dalam dirinya. Pentingnya minat belajar untuk memupuk konsistensi dalam pendidikan. Seorang yang pintar akademik di kelas jika tidak memiliki minat belajar yang utuh, maka kepintarannya akan tertinggal oleh siswa-siswi lainnya. Karenanya Hamalik dengan tegas mengaitkan minat belajar dengan kerangka mental seseorang. Hamalik mengkorelasikan ini karena menganalisis bukti eksternal dari tindakan nyata diluar kepada keinginan dan gairah dalam hati. Hasil dipotret dari kombinasi gerak dari tubuh (sikap, respon, gimik wajah) dengan perpaduan perasaan yang ada 

Anggi Maringan H, Yehezkiel V. Fernando

DOI: https://doi.org/10.31004/edukatif.v3i4.1114

didalam diri manusia. Dapat disimpulkan bahwa minat seorang pelajar bukanlah penilaian subjektif dari dalam, melainkan penilaian objektif yang terlihat dari gaya hidup sehari-hari (Hamalik, 2011).

Minat belajar menjadi hal penting yang harus setiap siswa-siswi miliki, karena hal tersebut dapat memberikan dorongan kepada diri sendiri untuk rajin belajar. Akibatnya secara otomatis akan memberikan suatu pengaruh di bidang akademis. Jika terdapat materi pelajaran yang sulit, siswa-siswi bukan menghindar dari pelajaran tersebut atau mencontek, melainkan berusaha semaksimal mungkin untuk mengerjakannya. Itu sebabnya Sujanto menegaskan bahwa minat belajar inilah yang dapat memberikan daya tahan dan daya juang untuk mencapai tujuan yang telah dibuat oleh siswa-siswi (Sujanto, 2013).

Susanto memaparkan faktor apa saja yang mempengaruhi minat belajar siswa. Pertama, motivasi mengapa ingin bersekolah. Pilihan mengapa ingin sekolah dan secara khusus bersekolah di SMTK adalah alasan fundamental yang mendorong minat belajar. Jika alasannya karena tidak diterima di sekolah lain, maka ketika menghadapi proses pembelajaran, maka siswa-siswi tersebut akan mudah untuk mundur. Kedua, dukungan keluarga. Keluarga yang mendukung dan memperhatikan perkembangan Pendidikan anak-nya akan memotivasi siswa-siswi untuk rajin belajar. Ketiga, peranan guru dalam mencapai keinginan dan cita-cita siswa-siswi. Keempat, sarana dan prasarana yang dimiliki oleh sekolah. Kelima, teman pergaulan. Jika selama menempuh Pendidikan siswa-siswi mendapatkan komunitas yang rajin belajar, maka akan memotivasi dirinya untuk ikut belajar. Demikian sebaliknya, jika komunitasnya adalah orang-orang yang tidak memiliki tujuan dalam Pendidikan, maka terbentuk siswa-siswi yang malas. Keenam, media massa/media elektronik (Nizar \& Hajaroh, 2019).

Sedangkan alasan mengapa siswa/i tidak memiliki minat belajar yang tinggi adalah sebagai berikut: Pertama, tidak tertarik dengan kurikulum yang dilaksanakan. Tidak dapat dipungkiri bahwa ada saja siswa/i yang tidak setuju dengan sistem pendidikan di Indonesia. Mereka selalu menyandingkan dengan pendidikan di Finlandia yang dianggap dapat mengakomodir keinginannya. Kedua, pembimbing yang tidak memadai. Beberapa faktor yang memotivasi siswa-siswi mengikuti bimbingan belajar adalah adanya dorongan dari orang tua, adanya keinginan untuk lebih memahami materi yang sudah disampaikan di sekolah. Hal ini didukung dengan adanya intensitas belajar mandiri di rumah, dan adanya cita-cita yang ingin dicapai (Khoerunnisa \& Grafiyana, 2019). Tetapi, dorongan itu terhambat karena dana yang diperlukan untuk membayar uang bimbingan. Ketiga, media belajar yang kurang menarik. Tugas siswa adalah belajar, interaksi yang menarik dapat membuat seorang siswa-siswi berminat dengan pembelajaran yang berlangsung. Tentu pembelajaran yang menarik bukan terlihat dari mewahnya teknologi yang canggih namun media pembelajaran dari kreativitas guru dalam mengajar siswa/inya. Ketika media pembelajaran kreatif membuat siswa menarik maka siswa/i secara otomatis akan mengikuti pelajaran dengan baik.

\section{Pendidikan Kristen di Era Postmodern}

Pendidikan adalah faktor yang mendukung kemajuan sebuah bangsa. Bangsa yang maju pasti dapat dinilai dari rakyat yang memiliki pola pikir kedepan yang mencintai bangsa dan negaranya. Hal ini menjadi masalah tersendiri mengingat era postmodern yang telah memasuki seluruh lapisan masyarakat. Corak berpikirnya telah merambah seluruh sisi kehidupan manusia, termasuk SMTK Bethel Jakarta. Dalam bidang teologi, istilah ini pertama kali digunakan oleh Bernard Iddings Bell pada tahun 1939 yang sedang berusaha memberi respon terhadap kegagalan modernisme sekuler dan kembalinya agama dalam kehidupan manusia (Aritonang, 2018). Modernisme dianggap gagal memberikan ruang kepada manusia untuk berpendapat. Itu sebabnya, Sinaga dalam tulisan Jan Aritonang menyatakan bahwa ada beberapa sifat yang menandakan corak berpikir postmodern, yaitu sikap curiga terhadap modern (sesuatu yang dianggap kebenaran), counter culture (mengecam apa yang selama ini dianggap sebagai budaya tertinggi), re-enchantment (memberikan kesempatan besar untuk cara berpikir baru dan segar untuk memahami imanensi Allah), membebaskan diri 
2404 Manfaat Penggunaan Gadget terhadap Minat Belajar Siswa Pendidikan Kristen pada Era Postmodern Anggi Maringan H, Yehezkiel V. Fernando

DOI: https://doi.org/10.31004/edukatif.v3i4.1114

dari supremasi rasio, dan membuka diri terhadap realitas pengalaman manusia yang harus dijunjung tinggi, serta wawasan pluralisme dan pluriformitas diangkat dan dipuji (Riemer, 2009).

Pluralisme dan relativisme tidak bisa dihindarkan pada era postmodern ini. Semangat ini sebenarnya sudah digaungkan oleh Race yang mengungkapkan tipologi tripolar dalam hubungannya dengan agamaagama (religionum) yaitu ekslusif, inklusif, dan pluralis (Aritonang, 2018). Akibatnya, Alkitab tidak lagi dijadikan sebagai dasar kebenaran yang utuh dan dasar dalam mengajar. Gerakan ini berasal dari pendirian filsafat yang mengarahkan kepada cara berpikir yang mandiri dan berbeda-beda (relative) sesuai apa yang dipandang baik. Kemutlakan akan suatu kebenaran adalah penyangkalan akan kebenaran itu sendiri (Darmawan, 2014).

Postmodern telah membawa dampak buruk bagi pendidikan Agama Kristen dalam kaitannya dengan Alkitab sebagai dasar, dan Yesus sebagai pusat pembentukan iman dan karakter. Sebagai contoh adalah negara yang mengedepankan Pendidikan Kristen telah mengalami degradasi yang drastis. Penelitian yang dilakukan oleh Pethtel mengungkapkan bahwa banyak perguruan tinggi dan sekolah Kristen yang didirikan pada prinsip-prinsip khusus Kristen dan memiliki akar atau fondasi iman Kristen yang kuat sudah terdegradasi. Pertimbangkan bahwa Harvard, Yale, Princeton, Dartmouth, dan beberapa lembaga pendidikan dasar lainnya di Amerika didirikan dengan cita-cita Kristen untuk pendidikan tetapi kehilangan akarnya dalam satu atau beberapa generasi sejak pendiriannya. Kehilangan misi dan visi pendidikan Kristen adalah masalah beberapa faktor. Salah satu faktor mungkin termasuk: hilangnya pemimpin, termasuk administrator, guru, dan anggota dewan, yang sebenarnya mendukung misi dan visi kerangka yang benar-benar alkitabiah untuk pembelajaran di sekolah Kristen (Pethtel, 2011).

Pemikiran siswa-siswi pendidikan Kristen tidak boleh terjerumus oleh pemikiran postmodern ini, karena dapat berakibat fatal. Alkitab tidak lagi menjadi standar kebenaran yang mutlak. Padahal dalam Pendidikan SMTK, tujuan utamanya bukan hanya pemenuhan ilmu dan pengetahuan dalam otak siswa. Melainkan perubahan karakter dan keteguhan untuk memegang prinsip kebenaran yang berasal dari Alkitab sebagai otoritas utama dalam mengajar. Alkitab memberikan pengertian-pengertian akan permasalahan yang terjadi di dunia ini. Disinilah yang menjadi tantangan dan keuntungan bagi Pendidikan Kristen agar mengajarkan kebenaran Alkitab melalui gadget.

Pendidikan Kristen era postmodern juga memasukkan kejiwaan dan sosial manusia. Keduanya adalah bagian integral dari kecerdasan yang mesti dimiliki oleh siswa-siswi. Dimulai dari pengajar yang mampu memahami satu persatu dari peserta didiknya, dan peserta didik yang memahami psikologi guru dan temanteman sekitarnya. Pembedaan ini bukanlah tindakan "pilih kasih" atau diskriminatif kepada orang lain. Tidak sama sekali mengajar kepada tindakan tersebut. Justru tindakan ini menjadi soft skill yang sangat bermanfaat bagi kehidupan siswa/i kelak setelah masuk dalam dunia kerja dan masyarakat. Oleh sebab itu, pendidik perlu memahami perkembangan individu peserta didiknya baik itu prinsip perkembangannya maupun arah perkembangannya (Novianti, 2015).

\section{Peran Pendidikan Agama Kristen di Era Postmodern}

Pendidikan agama Kristen adalah pendidikan yang menjawab tantangan zaman untuk melawan setiap pemikiran-pemikiran era postmodern ini. Era yang harus dilawan dengan strategi yang tepat dan ketekunan. Jika tidak dilawan maka siswa-siswi bisa percaya begitu saja sehingga kehilangan arah dalam minat belajar akan kebenaran Firman Tuhan, karena terpengaruh dari pemikiran yang mengedepankan kebenaran relative. Pendidikan agama Kristen adalah wadah gereja untuk menangkal setiap tantangan zaman yang mempengaruhi pemikiran-pemikiran yang melanggar dari ranah Alkitab. Inilah tanggung jawab seutuhnya untuk memanusiakan kembali kemanusian manusia secara utuh. Manusia kembali kepada rancangan yang telah Allah berikan yaitu segambar dan serupa dengan Dia (Hasiholan, 2020) Mengapa ini menjadi tujuannya? Fakta Alkitab menunjukan bahwa semua orang telah berdosa dan kehilangan kemuliaan Allah (Rm. 3:23). 
2405 Manfaat Penggunaan Gadget terhadap Minat Belajar Siswa Pendidikan Kristen pada Era Postmodern Anggi Maringan H, Yehezkiel V. Fernando

DOI: https://doi.org/10.31004/edukatif.v3i4.1114

Keberdosaan manusia itulah yang kemudian mengakibatkan semua manusia (tanpa terkecuali) mengalami keterbatasan dalam semua aspek kehidupan. Tetapi disisi lain, kita juga patut bersyukur bahwa oleh kasih karunia Allah sehingga manusia diberi kesempatan untuk memperbaiki kondisi hidupnya.

Postmodern bukan hanya tantangan guru atau siswa/i saja, namun orang tua harus terlibat dalam memberikan sosialisasi dalam memahami era ini. Visi dan misi yang diterapkan pendidikan sekolah harus terus-menerus diingatkan (Ul. 6:2-7). Untuk itu guru harus berperan aktif, jika muridnya tidak mau tergilas oleh bahayanya zaman ini. Peran pendidikan agama Kristen harus memberi manfaat yang lebih mendalam lagi dengan cara memahami setiap siswa-siswi. Disinilah gadget menjadi alat yang dapat memberikan pembelajaran yang kreatif, inovatif, dan motivatif. Dengan mengetahui bahwa Yesus Kristus sebagai teladan dalam perubahan seseorang maka siswa-siswi akan mempunyai pola pikir yang berstandar alkitabiah (Pantan, 2017). Berikut ini peneliti paparkan secara singkat peran guru Pendidikan Kristen atau SMTK:

\section{Memelihara warisan Nilai-nilai Pendidikan Yang dijalankan oleh Yesus Kristus dan Murid-muridNya}

Peneliti perlu tegaskan bahwa pendidikan Kristen yang sedang dijalani oleh siswa-siswi adalah pentradisian nilai-nilai kebenaran dari Yesus Kristus dan Para murid-Nya ribuan tahun yang lalu. Itulah sebabnya James memberikan rangsangan berpikir kepada kita berupa pertanyaan bahwa "apakah program pendidikan agama Kristen yang sekarang ini kita jalankan sudah dapat dianggap sebagai lanjutan (warisan) dari apa yang pernah dibuat oleh Yesus Kristus bersama-sama dengan murid-murid-Nya, jemaat pertama dengan orang Yahudi dan bukan Yahudi?" tentu saja, yang menjawab itu adalah masing-masing dari pengajar atau guru Pendidikan Agama Kristen. Lebih lanjut dikemukakan bahwa pendidikan dan pengajaran Yesus Kristus bertujuan untuk memberikan latihan misi (Smart, 2008). Karena itu, untuk mempelajari definisi pendidikan agama Kristen, harus digali dalam Alkitab khususnya dalam ajaran dan kehidupan Yesus Kristus (Pantan, 2017). Dengan demikian, SMTK harus menjadikan Yesus Kristus sebagai pusat dalam pendidikan Kristen.

\section{Mengasihi dan Mendidik Siswa-siswi dengan Hati}

Hanya ada sedikit hal yang sakral dalam dunia pada saat ini. Pendidikan Kristen terbenam dalam budaya yang tidak dapat menyadari pentingnya dikhususkan bagi Tuhan dan rencana-Nya. Guru ingin siswanya menerima kekudusan Allah dalam dunia yang telah jauh dari hidup bertentangan dengan segala sesuatu yang kudus. Namun bagaimana guru Pendidikan Kristen dapat membantu mereka melakukan hal ini? Bagaimana melatih siswa/i untuk menjalankan hidup yang kudus dalam dunia yang bertentangan dengan kekudusan. Guru Pendidikan Kristen mesti menyadari dan kembali kepada pemahaman bahwa tanpa kelahiran baru yang sejati, pengajaran yang disampaikan akan tetap berada dalam permukaan. Tanpa hubungan yang intim pribadi dengan Yesus Kristus, pengajaran kita tidak akan mengubah kehidupan. Dengan memasukkan aspek spiritual, maka pembelajaran dapat mengubahkan hidup siswa/. Inilah keunikan dari SMTK Bethel Jakarta sebagai Pendidikan Kristen (Caperhart, 2012).

Siswa/i yang berhasil adalah siswa/i yang punya integritas tinggi, takut akan Tuhan dan berkarakter seperti Kristus. Pemahaman akan perjuangan ini harus lahir dari siswa/i yang mau diajar dan berniat untuk berubah. Tentu dalam perubahan anak siswa/i ada fase dalam posisi jatuh dan bangun. Untuk itulah guru harus mempunyai hati untuk mengajar, Guru bukan pengubah anak siswa/i dari nakal menjadi patuh namun guru perantara dalam perubahan siswa/I (Ermindyawati, 2019).

\section{Guru Sebagai Pemberita Injil}

Guru adalah misionaris bagi siswa. Hal ini menjelaskan bahwa betapa pentingnya pemberitaan Injil yang dapat menyelamatkan manusia dari dosa kepada kebenaran, termasuk siswa (Telaumbanua, 2018) Pemahaman ini semestinya membuat pandangan guru Pendidikan Kristen berbeda kepada siswa/inya. Siswa/I 

Anggi Maringan H, Yehezkiel V. Fernando

DOI: https://doi.org/10.31004/edukatif.v3i4.1114

bukanlah objek pelampiasan emosi karena kekurangan yang dimiliki, melainkan insan-insan yang berharga. Memberitakan Injil adalah tugas yang mengarah kepada menyelamatkan siswa/I dari arus pergaulan yang rusak. Guru harus membawa siswa/i untuk tidak terjun pada pergaulan kurang baik. Dalam 1 korintus 15:33 "janganlah sesat: Pergaulan yang buruk merusakkan kebiasaan yang baik", ayat diatas dapat disimpulkan bahwa pergaulan yang buruk akan merusakkan kebiasaan yang baik. Kebiasaan yang sudah dibangun sedari kecil takut akan Tuhan, mengasihi sesama, rajin akan rusak jika seorang siswa/i salah dalam pergaulan yang tidak membuat dirinya bertumbuh (Lickona, 2013).

Hubungan antara guru bisa dilakukan layaknya seorang sahabat sehingga siswa/i tidak selalu ketakutan jika siswa/i kedapatan melakukan kesalahan. Harus dihapuskan pemikiran bahwa guru selalu benar dan siswa/i salah dalam memberi saran, namun seharusnya guru terbuka dengan saran yang disampaikan siswa/i, untuk itulah hubungan layaknya seorang sahabat diperlukan dalam hal ini. El-Baz menyarankan supaya di era postmodern ini, guru dapat membantu siswa menyadari bahwa mereka adalah bagian dari masyarakat pengetahuan, dan ini melalui pendalaman yang lain budaya yang mereka miliki. Selanjutnya membantu siswa memberikan pendapat yang berbeda sesuai dengan keyakinan mereka. Dan terahkir membantu siswa memahami sifat pengetahuan dari berbagai aspek seperti sosial dan sejarah (El-Baz, 2017).

Riofita memberikan beberapa cara supaya hubungan persahabatan dapat terjalin. Pertama, guru mesti mengenali satu persatu dari siswa/Inya. Jangan memukul rata kemampuan setiap murid. Kedua, lakukan komunikasi yang efektif yaitu menanyakan sesuatu bukan hanya terkait tugas di kelas, tetapi kesulitankesulitan yang dihadapi oleh siswa/i. Ketiga, bangun kepercayaan dengan memiliki integritas dalam kehidupan mengajar dan kehidupan sehari-hari. Keempat, membangun kerjasama di berbagai kegiatan atau project. Dengan membangun kerja sama ini, siswa/I tidak memiliki rasa sungkan untuk berbicara dengan gurunya, melainkan saling mendukung. Kelima, menjaga kebersamaan secara formal ketika mengajar, dan secara informal yaitu ketika diluar jam belajar (Riofita, 2014).

\section{Pemanfaatan Gadget bagi Minat Belajar Siswa/I SMTK Bethel Jakarta di Era Postmodern}

Narasumber menyatakan bahwa gadget adalah alat yang sangat dekat dengan mereka. Dari data yang didapat, hampir 75\% siswa-siswi SMTK Bethel Jakarta menggunakan gadget selama 10-15 jam per hari. Sementara yang menggunakan 1-5 dan 15-20 jam hanya 3\% saja seperti tabel dibawah ini:

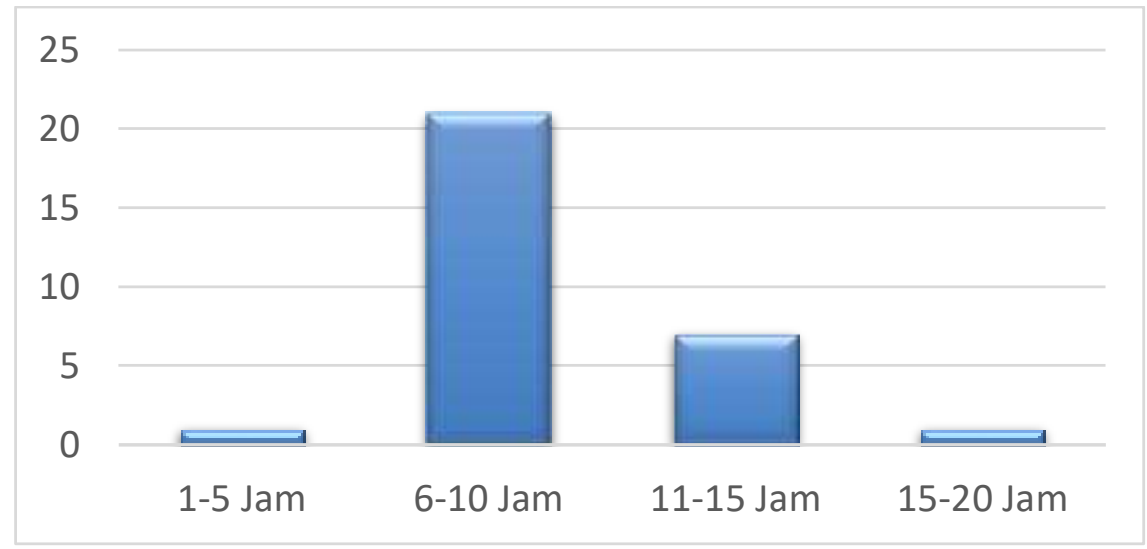

Grafik 1. Durasi Penggunaan Gadget per hari

Melalui wawancara mendalam kepada 7 orang yang menggunakan gadget selama 6-10 tahun karena alasan pembelajaran online dari pagi hingga siang. Selanjutnya mereka menggunakan untuk mengakses media sosial seperti Youtube, Instagram, dan Whatsapp. Angka yang tinggi ini tentunya bukan tanpa sebab. Sebab dalam pendidikan pandemic Covid-19 yang menerapkan sistem sinkronus dan asinkronus menyebabkan siswa-siswi mesti melakukan pertemuan kelompok diluar jam belajar secara virtual. Hal ini yang menjadi 
alasan mengapa mereka lama menggunakan gadget. Fakta ini sejalan dengan penelitian yang dilakukan oleh (Junawan \& Laugu, 2020) yang mencatat kenaikan pengaksesan media sosial hingga 88\% dikarenakan pembelajaran dilakukan secara online. Sedangkan yang menggunakan hingga 11-15 jam karena aktivitas lanjutannya adalah bermain games online.

Dalam wawancara mendalam yang dilakukan peneliti, mayoritas narasumber menyukai games sebagai sarana belajar. Menurut narasumber games online dapat menjadi wadah untuk bersosialisasi dengan siswasiswi dari sekolah lain. Beberapa diantaranya mendapatkan teman baru karena bermain games online yang dapat terhubung dengan siapa saja dan dimana saja. Hanya beberapa saja yang memainkan games untuk hiburan setelah seharian belajar. Fakta ini berbeda dengan penelitian-penelitian sebelumnya yang dilakukan dalam memandang games online ini. Seperti yang dilakukan oleh (Suplig, 2017) yang menyatakan bahwa dampak negatif dari games online amat besar. Games online dapat membuat remaja lupa waktu, gangguan kognitif, insomnia (gangguan fisik), masalah sosial, tidak menghormati Tuhan karena gagal menggunakan waktu dengan baik. Demikian dengan (Santoso, 2020) yang menyoroti sosialisasi dengan masyarakat dan penggunaan waktu sebagai dampak negatif dari gadget atau gawai. Justru di SMTK Bethel Jakarta, gadget adalah alat yang positif dalam kedua bagian itu.

Fakta bahwa games online amat diminati oleh siswa-siswi SMTK Bethel Jakarta, dimanfaatkan oleh oleh guru SMTK dalam mengajar. Dalam wawancara yang dilakukan pada 10 Juni 2021 kepada dua guru dengan inisial KJ dan AM disampaikan bahwa dalam kegiatan belajar mengajar, guru SMTK Bethel Jakarta menggunakan aplikasi games online edukasi quizizz. Quizizz adalah perusahaan software kreativitas yang digunakan dalam kelas, kerja kelompok, review pre-test, ujian, tes unit, dan tes dadakan. Ini memungkinkan siswa dan guru untuk online pada waktu yang sama. Beberapa fitur diantaranya berupa; adanya hitungan waktu mundur dalam mengerjakan soal, adanya meme berkarakter ketika siswa kurang tepat dalam menjawab soal, adanya penghargaan yang bersifat acak saat siswa menjawab soal dengan benar, serta adanya sistem peringkat sehingga siswa termotivasi untuk mengerjakan soal dengan cepat, benar, dan teliti. Pendapat tersebut sesuai dengan yang Zhao kemukakan dalam penelitiannya yang berbunyi, “... using Quizizz doing inclass exercise is fun, helps them review the course materials and stimulates their interest in learning..." (Solikah, 2020).

Guru SMTK dengan inisial JH sangat bersyukur diperkenalkan games online berbasis pelajaran ini. Sebagai guru inti dalam pendidikan Agama Kristen namun bosan untuk dipelajari oleh siswa-siswi karena memuat banyak sejarah dan bahasa-bahasa yang jarang didengar secara umum (penggunaan bahasa IbraniYunani), yaitu dogmatika Kristen quizizz memberikan suasana baru dalam belajar yang selama ini tidak pernah digunakan dalam pembelajaran tatap muka. Kreativitas dari guru SMTK Bethel Jakarta mempermudah siswa dalam memahami materi pelajaran dogmatika. Selain itu, fitur yang disajikan telah membuat minat siswa menjadi meningkat. Hal tersebut meningkatkan minat belajar siswa-siswi dengan baik, sehingga aktivitas siswa/i tidak terbuang sia-sia dengan pembelajaran yang membuat siswa/i bosan. Disinilah kecermatan guru-guru SMTK Bethel Jakarta mengubungkan games dengan mata pelajaran Agama Kristen sesuai dengan penelitian (Nizar \& Hajaroh, 2019) yang menyatakan guru sebagai instrument minat belajar siswa.

Dengan diperkenalkan dan digunakannya games ini dalam proses belajar mengajar Agama Kristen, siswa-siswi dapat mengontrol jam bermain gadgetnya untuk games dengan baik. Data dari wawancara mendalam menyatakan bahwa pemberian makna bermain games oleh guru SMTK Bethel Jakarta ketika di kelas membuatnya berubah dalam tujuan bermain games. Hal ini sesuai dengan pernyataan (Khoerunnisa \& Grafiyana, 2019) tentang bagaimana meningkatkan minat belajar siswa, yaitu motivasi belajar. Motivasi bermain games diarahkan kepada belajar dan prestasi di kelas. Games bukan lagi kecanduan yang menyebabkan prestasi belajar menurun, dan sosialisasi dengan orang lain tidak berjalan. Justru games adalah alat untuk dapat belajar lebih mudah dan mendapatkan banyak teman. 
Guru SMTK Bethel Jakarta tetap berkomitmen untuk mencapai visi-misi dari Pendidikan Kristen yaitu siswa-siswi yang menerima Kristus sebagai Tuhan dan Juruselamt secara pribadi sehingga hidup sesuai dengan kehendak-Nya. Dari dasar pijakan ini, maka Pendidikan Kristen menelisik kepada kehidupan beriman dari siswa-siswi yang ikut dalam proses belajar mengajar. Asumsi yang dipegang bahwa sebaik apapun metode dalam mengajar, jika tidak menyentuh esensi ini maka proses belajar mengajar dinyakatan gagal. Indikator yang digunakan tentunya berbeda dengan sistem Pendidikan lain yang memiliki tujuan melahirkan orang-orang yang pintar secara akademis. Pendidikan hadir hadir untuk melahirkan siswa-siswa yang menghidupi karakater Kristus. Karena itu diperlukan usaha sedemikian rupa untuk mencapai tujuan dari pembelajaran PAK (Wongkar \& Sumarno, 2020).

Peneliti menyadari bahwa penelitian ini dilakukan setelah para guru SMTK Bethel Jakarta secara masif mengajarkan makna bermain gadget untuk membangkitkan minat belajar. Bahkan terdapat kontrol dari guruguru pembimbing secara personal kepada para siswa-siswi. Dengan menggunakan aplikasi games online dalam proses belajar, maka pendidikan Agama Kristen mendapat dua manfaat (i) internalisasi nilai-nilai iman Kristen akan lebih mudah; (ii) penggunaan games online tidak selalu kepada dampak negatif, justru kearah positif dalam memaknai games online untuk mendapatkan teman baru, dan mengatur waktu. Penelitian ini belum memotret bagaimana pandangan orang tua terkait games online. Sebab selama ini games selalu dikonotasikan negatif, dan peneliti tidak sampai kepada bagian mengubah paradigma orang tua siswa-siswi ketika melihat anaknya bermain games online.

\section{KESIMPULAN}

Bedasarkan penelitian yang dilakukan, di SMTK Bethel Jakarta didapati bahwa pendidikan Kristen pada era postmodern dengan corak berpikir relatif dan pluralis yang menyebabkan siswa-siswi tidak lagi berpegang kepada Alkitab sebagai dasar iman mereka dapat disiasati dengan menggunakan gadget sebagai media pembelajaran primer. Karenanya, pendidikan Kristen tidak perlu lagi khawatir dengan generasi muda Kristen kedepan. Ketidak khawatiran ini berangkat dari guru-guru Pendidikan Kristen yang sudah menemukan metode internalisasi nilai-nilai kebenaran Firman Tuhan kepada siswa-siswinya. Hal ini telah dilakukan oleh SMTK Bethel Jakarta pada masa pandemic Covid-19 ini. Diharapkan guru Pendidikan Agama Kristen inovatif dalam mengajar. Jangan hanya terpatok kepada powerpoint, teks book, dan tugastugas dalam pembelajarannya. Tetapi gunakan games-games yang ada agar proses internalisasi iman Kristen dengan mudah diterima siswa-siswi. Guru Agama Kristen juga mesti mengontrol prilaku media sosial dan games online siswa dalam kehidupan sehari-hari. Karena itu, diperlukan adanya guru pembimbing akademik atau wali kelas yang pro-aktif memantau dan memperhatikan sebagai teman sehingga hubungan keduanya sehat dan baik.

\section{UCAPAN TERIMA KASIH}

Penulis berterima kasih kepada responden dari jajaran SMTK Bethel Jakarta yang bersediauntuk dilakukan penelitian selama tiga bulan yang terhitung dari bulan April hingga Juni 2021. Penulis juga tidak lupa mengucapkan terima kasih kepada reviewer jurnal Edukasi yang memberikan arahan-arahan supaya terciptanya jurnal penelitian yang dapat memberi sumbangsih khazanah dalam Pendidikan Agama Kristen.

\section{DAFTAR PUSTAKA}

Aritonang, J. S. (2018). Teologi-Teologi Kontemporer. Bpk Gunung Mulia.

Caperhart, J. (2012). Teaching With Heart (J. The (Ed.)). Metanoia. 
2409 Manfaat Penggunaan Gadget terhadap Minat Belajar Siswa Pendidikan Kristen pada Era Postmodern Anggi Maringan H, Yehezkiel V. Fernando

DOI: https://doi.org/10.31004/edukatif.v3i4.1114

Darmawan, I. P. A. (2014). Pendidikan Kristen Di Era Postmodern. Stt Simpson, 1(2), 37-46.

El-Baz, M. B. M. S. (2017). Post Modernity Theory And Its Educational Applications In School Fields. $\begin{array}{lllll}\text { Journal Of Education And } & \text { Practice, }\end{array}$ Http://Ezproxy.Lib.Uconn.Edu/Login?Url=Https://Search.Ebscohost.Com/Login.Aspx?Direct=True\&Db $=$ Eric $\& A n=E j 1143816 \&$ Site $=$ Ehost-Live

Eliasaputra, M. P., Novalina, M., \& Siahaan, R. J. (2020). Tantangan Pendidikan Agama Kristen Di Era Revolusi Industri 4.0 Dan Pasca Kebenaran. Bonafide: Jurnal Teologi Dan Pendidikan Kristen, 1(1), 122. Https://Doi.Org/10.46558/Bonafide.V1i1.7

Ermindyawati, L. (2019). Peranan Guru Pendidikan Agama Kristen Terhadap Perilaku Siswa-Siswi Di Sd Negeri 01 Ujung Watu Jepara. Fidei: Jurnal Teologi Sistematika Dan Praktika, 2(1), 40-61. Https://Doi.Org/10.34081/Fidei.V2i1.27

Hamalik, O. (2011). Metode Belajar Dan Kesulitan Belajar. Tarsito.

Hasiholan, A. M. (2020). Studi Komparatif Terhadap Pemahaman Teologi Reformed Dengan Pemahaman Teologi Pentakosta Tentang Natur Manusia. Pneumata, 1(1), 54-71.

Hudaya, A. (2018). Pengaruh Gadget Terhadap Sikap Disiplin Dan Minat Belajar Peserta Didik. Research And Development Journal Of Education, 4(2), 86-97. Https://Doi.Org/10.30998/Rdje.V4i2.3380

Intan Trivena Maria Daeng, Mewengkang, N. ., \& Kalesaran, E. R. (2017). Penggunaan Smartphone Dalam Menunjang Aktivitas Perkuliahan Oleh Mahasiswa Fispol Unsrat Manado Oleh. E-Journal "Acta Diurna," 6(1), 1-15.

Junawan, H., \& Laugu, N. (2020). Eksistensi Media Sosial,Youtube, Instagram Dan Whatsapp Ditengah Pandemi Covid-19 Dikalangan Masyarakat Virtual Indonesia. Baitul 'Ulum: Jurnal Ilmu Perpustakaan Dan Informasi, 4(1), 41-57. Https://Doi.Org/10.30631/Baitululum.V4i1.46

Kelellufna, V. P., \& Masan, A. L. (2016). Meningkatkan Prestasi Belajar Siswa Sma Pada Materi Gelombang Bunyi Menggunakan Strategi Multiple Intelligences. Jurnal Pedagogika Dan Dinamika Pendidikan, $4(2), 87-95$.

Khoerunnisa, E., \& Grafiyana, G. A. (2019). Motivasi Siswa Mengikuti Bimbingan Belajar. Psisula: Prosiding Berkala Psikologi, 1, 43. Https://Doi.Org/10.30659/Psisula.V1i0.7687

Kurniawati, D. (2020). Pengaruh Penggunaan Gadget Terhadap Prestasi Siswa. Edukatif: Jurnal Ilmu Pendidikan, 2(1), 78-84. Https://Doi.Org/10.31004/Edukatif.V2i1.78

Lickona, T. (2013). Pendidikan Karakter: Panduan Lengkap Mendidik Siswa Menjadi Pintar Dan Baik. Nusa Media.

Moleong. (2010). Metodologi Penelitian Kualitatif. Remaja Rosdakarya.

Nizar, A., \& Hajaroh, S. (2019). Pengaruh Intensitas Penggunaan Game Gadget Terhadap Minat Belajar Siswa. El Midad: Jurnal Pgmi, 11(2), 169-192. Https://Doi.Org/10.20414/Elmidad.V11i2.1901

Novianti. (2015). Peranan Psikologi Pendidikan Dalam Proses Belajar Mengajar. Jupendas, Issn 2355-3650, Vol. 2, No. 2, September 2015, 2(2).

Pantan, F. (2017). Ontologi Pendidikan Iman Kristen. In J. Gultom (Ed.), Education For Change. Bethel Press.

Pethtel, G. (2011). Christian Education In The 21st Century: Renewing A Transformational Vision [Cedarville University]. In Christian Education In The 21st Century: Renewing A Transformational Vision. Https://Doi.Org/10.15385/Tmed.2011.4

Pusparisa, Y. (2020). Pengguna Smartphone Diperkirakan Mencapai 89\% Populasi Pada 2025. Databox. Https://Databoks.Katadata.Co.Id/Datapublish/2020/09/15/Pengguna-Smartphone-Diperkirakan-

Mencapai-89-Populasi-Pada-2025 
2410 Manfaat Penggunaan Gadget terhadap Minat Belajar Siswa Pendidikan Kristen pada Era Postmodern Anggi Maringan H, Yehezkiel V. Fernando

DOI: https://doi.org/10.31004/edukatif.v3i4.1114

Riemer, G. (2009). Gereja-Gereja Reformasi Di Indonesia. Bpk Gunung Mulia.

Riofita, H. (2014). Padamu Pahlawan Tanpa Tanda Jasa (Menjadi Guru Ideal). Subentra.

Rosiyanti, H., \& Muthmainnah, R. N. (2018). Penggunaan Gadget Sebagai Sumber Belajar Mempengaruhi Hasil Belajar Pada Mata Kuliah Matematika Dasar. Fibonacci: Jurnal Pendidikan Matematika Dan Matematika, 4(1), 25. Https://Doi.Org/10.24853/Fbc.4.1.25-36

Santoso, F. A. (2020). Dampak Penggunaan Gawai Terhadap Pembelajaran Siswa Sekolah Dasar. Edukatif: Jurnal Ilmu Pendidikan, 2(1), 49-54. Https://Doi.Org/10.31004/Edukatif.V2i1.87

Smart, J. (2008). The Teaching Ministry Of The Church. Westminster Press.

Solikah, H. (2020). Pengaruh Penggunaan Media Pembelajaran Interaktif Quizizz Terhadap Motivasi Dan Hasil Belajar Siswa Pada Materi Teks Persuasif Kelas Viii Di Smpn 5 Sidoarjo Tahun Pelajaran 2019/2020. Bapala, 7(3), 1-8.

Sugiyono. (2015). Metode Penelitian Kualitatif Dan R And D. In Bandung: Alfabeta. Alfabeta.

Sujanto, A. (2013). Psikologi Umum. Aksara Baru.

Suplig, M. A. (2017). Pengaruh Kecanduan Game Online Siswa Sma Kelas X Terhadap Kecerdasan Sosial $\begin{array}{llllll}\text { Sekolah Kristen Swasta Di Makassar. Jurnal } & \text { Jafray, }\end{array}$ Https://Doi.Org/10.25278/Jj71.V15i2.261

Telaumbanua, A. (2018). Peranan Guru Pendidikan Agama Kristen Dalam Membentuk Karakter Siswa. Fidei: Jurnal Teologi Sistematika Dan Praktika, 1(2), 219-231. Https://Doi.Org/10.34081/Fidei.V1i2.9

Wongkar, A. A., \& Sumarno, Y. (2020). Agama Kristen Melalui Penerapan Strategi Pembelajaran Contextual Teaching And Learning. Edukasi: Jurnal Pendidikan Agama Kristen, 11(1), 1-7.

Xiao, A. (2018). Konsep Interaksi Sosial Dalam Komunikasi, Teknologi, Masyarakat. Jurnal Komunika : Jurnal Komunikasi, Media Dan Informatika, 7(2). Https://Doi.Org/10.31504/Komunika.V7i2.1486

Yulianti, R. R. M., Syatoto, I., Suroto, S., Suprapti, E., \& Elburdah, R. P. (2020). Pengaruh Game Online Terhadap Minat Belajar Siswa Mts Matlail Anwar. Jurnal Pengabdian Dharma Laksana, 03(1), 62-67. Https://Doi.Org/10.32493/J.Pdl.V3i1.6283 